\title{
Gas Exchanges of Yellow Capsicum Fertilized with Yellow Water and Cassava Wastewater
}

\author{
Jailton Garcia Ramos ${ }^{1}$, Vera Lucia Antunes de Lima ${ }^{1}$, Ronaldo do Nascimento ${ }^{1}$, Rafaela Felix Basílio Guimarães ${ }^{1}$, \\ Mariana de Oliveira Pereira ${ }^{1}$, Narcísio Cabral de Araújo $^{1}$, Daniele Ferreira de Melo ${ }^{1}$ \\ $\&$ Sabrina Cordeiro de Lima ${ }^{1}$ \\ ${ }^{1}$ Federal University of Campina Grande, Brazil \\ Correspondence: Jailton Garcia Ramos, Federal University of Campina Grande, Brazil. E-mail: \\ jailtonbiossistemas@gmail.com
}

Received: September 23, 2017

Accepted: October 20, 2017 Online Published: November 15, 2017

doi:10.5539/jas.v9n12p316

URL: https://doi.org/10.5539/jas.v9n12p316

\begin{abstract}
Wastewater reuse has increasingly become a sustainable alternative to the efficient use of water as well as the mitigation of the negative environmental impacts generated by the release of the water to the environment in an indiscriminate way. Thus, it is very important to know and evaluate the physiological variables of gas exchanges of plants cultivated with these waters, in order to obtain precise answers their effects on plant physiology. The present study aimed to evaluate the gas exchange of yellow capsicum cultivated in soil fertilized with human urine and cassava wastewater. The experiment was conducted in a protected environment at the Federal University of Campina Grande, Campina Grande - PB. A completely randomized design with eight treatments and five replications was used. The treatments were cattle manure (T1); NPK (T2); human urine treated (T3); cassava wastewater (T4); (T3)+(T4); $2 \mathrm{x}(\mathrm{T} 3) ; 2 \mathrm{x}(\mathrm{T} 4) ; 2 \mathrm{x}(\mathrm{T} 3+\mathrm{T} 4)$. The volumes of the biofertilizers were defined according to the nitrogen and potassium contents of urine and cassava wastewater, respectively. At 15 and 30 days after transplanting, the variables of gas exchange, the efficient use of water and the instantaneous efficacy of carboxylation were evaluated. The data were submitted to Tukey test at $5 \%$ probability. The results indicated that there wasn't statistical difference for efficient use of water (UEA) evaluated at 30 DAT.The treatment 5 provided the best results in relation to gas exchange, for the variables internal concentration of $\mathrm{CO}_{2}(\mathrm{Ci})$, net assimilation rates of $\mathrm{CO}_{2}(\mathrm{~A})$, stomatal conductance (gs), leaf transpiration (E), higher efficiency of water use (UEA) and instantaneous carboxylation efficiency at 15 DAT, so for 30 DAT the biofertilizer that provided the best results was the T4 treatment, although there weren't significant statistical differences among the treatments for (UEA), except for of T5.
\end{abstract}

Keywords: Capsicum annumm, agricultural use of waste, human urine, eco-sanitation

\section{Introduction}

The capsicum (Capsicum annuum L.) is one of the vegetable-fruit crops of the Brazilian market that presents a great seasonality of supply and price, being among the ones that present majorarea cultivated in all Brazil (Oliveira et al., 2009, Filgueira, 2008). This crop is very demanding in nutrients, and as the Brazilian soils generally have low fertility, it is necessary to use mineral or organic fertilization (Sediyama et al., 2009).

The use of solid and liquid organic fertilizers in agricultural production has shown a growth due to the high cost of chemical fertilizers (Oliveira et al., 2016). Dantas et al. (2015) affirms that the use of cassava wastewater and human urine treated has great potential as a source of nutrients for plants, since they have high levels of nitrogen $(\mathrm{N})$, phosphorus $(\mathrm{P})$, potassium $(\mathrm{K})$, calcium $(\mathrm{Ca})$ and magnesium $(\mathrm{Mg})$. In the face of the water scarcity scenario, the search for alternative sources to supply the needs of plants has been constant. In this context, the use of cassava wastewater and human urine as a source of water for irrigation and at the same time of fertilizer for the plants, allows a reduction of environmental impacts due to the release of these effluents in an inadequate way in the water bodies, besides contributing to an increase in yield of crops due to high concentration of nutrients (Cardoso et al., 2009).

Although yellow water or human urine possesses high fertility potential, being rich in macro and micro nutrient essences for plant development, this potential is still underestimated and underutilized (Goldstein, 2012; Netting, 
1993; Lind et al., 2001). In a study conducted by Araújo et al. (2015) the use of human urine treated proved to be effective for the production of hydroponic green maize fodder.

Therefore, evaluating and seeking to understand the answers about the physiological parameters of plants with economic and production potential, when cultivated under different types of organic fertilization is of paramount importance, especially when the fertilization is still from wastewater, when discarded indiscriminately, without treatment, pose a risk of pollution to the environment.

In this context, this work had as objective to evaluate the physiological parameters of gas exchanges of yellow capsicum, Satrapo hybrid, cultivated in protected environment and fertilized with human urine treated and cassava wastewater.

\section{Material and Methods}

The study was carried out in a greenhouse from October to December 2016, at Campus I of the Federal University of Campina Grande (UFCG), Campina Grande-PB. The greenhouse, with an area of $30 \mathrm{~m}$ long by 22 $\mathrm{m}$ wide, with $660 \mathrm{~m}^{2}$, with a metallic structure, being of the cover and arch type, covered with polyethyleneof low density of $150 \mu \mathrm{m}$ and sides covered with shading screen with index of $80 \%$ protection.

The capsicum seedlings were produced in a nursery located near the greenhouse, covered with polyethyleneof low density of $150 \mu \mathrm{m}$ and sides covered with a shading screen with index of $80 \%$ protection. For the production of the seedlings was used as substrate humusof bovine manure and soil in the proportion of 1:1 v/v, placed in 50 plastic cups of $100 \mathrm{ml}$ each. Three yellow capsicum seeds (Satrapo hybrid) were sown in each glass and irrigated twice a day, in the early morning and late afternoon.

At 30 days after sowing (DAS), when the seedlings presented between four and six leaves completely open, transplanting was performed. For this stage 40 seedlings were selected according to the homogeneity among them by means of visual parameters of turgor, height, stem diameter and number of leaves.

Transplanting was carried out in 40 pots with a capacity of 20 liters, with a spacing of $1 \mathrm{~m}$ between row and 0.5 $\mathrm{m}$ between rows, at $0.5 \mathrm{~m}$ from the soil, containing at its base a drain with a diameter of $0.05 \mathrm{~cm}$ connected to a PET bottle for collection and recirculation of the drained volume, geotextile blanket and $0.6 \mathrm{~kg}$ of gravel.

The methodology of conducting the experiment (irrigation management) followed the one described by Lima et al. (2015) by means of drainage lysimeter.

The soil used in the experiment and the production of the seedlings had the following physico-chemical characteristics: $\mathrm{pH}$ in water $(1: 2: 5)=5.58 ; \mathrm{CE}=0.56 \mathrm{mmhos} \mathrm{cm}^{-1} ; \mathrm{Al}=0.00 \mathrm{cmolc} \mathrm{dm}^{-3} ; \mathrm{Mg}=2.78 \mathrm{cmolc} \mathrm{dm}^{-3}$; $\mathrm{Ca}=9.07 \mathrm{cmolc} \mathrm{dm}^{-3} ; \mathrm{K}=0.33 \mathrm{cmol} \mathrm{dm}^{-3} ; \mathrm{Na}=1.64 \mathrm{cmolc} \mathrm{dm}^{-3} ; \mathrm{P}=3.98 \mathrm{cmolc} \mathrm{dm}^{-3} ; \mathrm{S}=13.72 \mathrm{cmol} \mathrm{dm}^{-3}$; Organic Carbon $=1.70 \%$; Organic matter $=2.93 \%$ and soil density $=1.28 \mathrm{~g} \mathrm{~cm}^{-3}$; textural class: loamy-clayey.

After filling the pots with $26 \mathrm{~kg}$ of soil, this was placed in the field capacity, with an applied blade of $2.3 \mathrm{~L}$ of rainwater with $\mathrm{CE}=0.04 \mathrm{dScm}^{-1}$.

It was used a completely randomized experimental design, with eight treatments and five replications, totaling 40 experimental plots. The treatments were defined by soil fertilization using bovine manure (T1-EB); NPK (T2-NPK); fertilization with human urinetreated (T3-UH); cassava wastewater treated (T4-MANI); human urine plus cassava wastewater treated (T5-(T3)+(T4)), twice the volume of human urinetreated $(\mathrm{T} 6-2 \mathrm{x}(\mathrm{T} 3))$, twice the volume of cassava wastewater treated (T7-2x(T4)) and twice the volume of human urine plus twice the volume of cassava wastewater treated (T8-2x(T3+T4)).

The estimation of the volume of human urine and cassava wastewater applied as treatment was based on the recommendation of Novais et al. (1991) in the concentrations of nitrogen and potassium present in human urine and cassava wastewater, respectively. In the case of T3 (UH), $170 \mathrm{~mL}$ of human urine $\left(80.67 \mathrm{~m}^{3} \mathrm{ha}^{-1}\right)$ were used; in T4 (M) $570 \mathrm{~mL}$ of cassava wastewater $\left(80.67 \mathrm{~m}^{3} \mathrm{ha}^{-1}\right)$ were applied; in T5 $(\mathrm{UH}+\mathrm{M})$ was applied with $170 \mathrm{~mL}$ of human urine plus $570 \mathrm{~mL}$ of cassava wastewater $\left(104.73 \mathrm{~m}^{3} \mathrm{ha}^{-1}\right)$; T6 $(2 \mathrm{xUH}) 340 \mathrm{~mL}$ of human urine $(48,12$ $\left.\mathrm{m}^{3} \mathrm{ha}^{-1}\right)$ were used; $1140 \mathrm{~mL}$ of cassava wastewater $\left(161.34 \mathrm{~m}^{3} \mathrm{ha}^{-1}\right)$ was applied to $\mathrm{T} 7(2 \mathrm{xM})$; and $340 \mathrm{~mL}$ of human urine plus $1140 \mathrm{~mL}$ of cassava wastewater $\left(209.46 \mathrm{~m}^{3} \mathrm{ha}^{-1}\right)$ were applied to T8 $(2 \mathrm{x}(\mathrm{UH}+\mathrm{M}))$.

The amount of bovine manuretanned applied was based on the methodology of Ribeiro et al. (1999), which is equivalent from 20 to $40 \mathrm{t} \mathrm{ha}^{-1}$ for pot of capsicum cultivation, still according to the authors, this dose meets the recommendation of fertilization with bovine manure tanned for this crop. The dose used in the present study was $85 \mathrm{mg} \mathrm{dm}^{-3}$, assuming a $50 \% \mathrm{~N}$ mineralization rate, thus the amount of bovine manure added and homogenized to the soil was $100 \mathrm{~g}$ per pot. 
The mineral fertilization with nitrogen, phosphorus and potassium was based on the recommendations of Novais et al. (1991) for potting experiments, applying the amounts of 100,300 and $150 \mathrm{mg} \mathrm{kg}^{-1}$ of soil of $\mathrm{N}_{2} \mathrm{P}_{2} \mathrm{O}_{5}$ and $\mathrm{K}_{2} \mathrm{O}$, respectively, in the form of urea, simple superphosphate and potassium chloride.

The human urine used was collected in three residences in the city of Campina Grande - PB. Afterwards the effluent was submitted to an anaerobic treatment, which was stored in a plastic drum with a capacity of 20 liters and kept hermetically closed for a period of 60 days. The treatment promoted anincrease $\mathrm{pH}$ (Table 1) and consequently the inactivation of possible pathogenic microorganisms that are present in the effluent.

The cassava wastewater was collected in a flour house located in the Jenipapo district of the municipality of Puxinanã - PB, and was also submitted to an anaerobic digestion process in a container of $85 \mathrm{~L}$ capacity that was kept closed for a period of 180 days.

An empty space of $10 \mathrm{~cm}$ was left inside the container between the effluent and the container lid. In the lid was placed a hose with the other end connected to a PET bottle with water at the height of $10 \mathrm{~cm}$ to release the gases generated during the digestion of the effluent. After the effluent storage period, the physical-chemical characterization of the human urine and cassava wastewater used was performed (Table 1).

Table 1. Physical-chemical characterization of human urine and cassava wastewater

\begin{tabular}{llllllll}
\hline & $\mathrm{NTK}$ & $\mathrm{N}_{\mathrm{NH}}$ & $\mathrm{P}_{3} \mathrm{PO}_{4}^{-3}$ & $\mathrm{~K}$ & $\mathrm{Na}$ & $\mathrm{pH}$ & $\mathrm{CE}$ \\
& - & $----\mathrm{dS} \mathrm{cm}^{-1}--$ \\
\hline Urine & 8.706 & 6.737 & 0.325 & 1.097 & 2.455 & 9.32 & 42.7 \\
Cassava & 1.680 & 0.933 & 0.338 & 3.948 & 0.138 & 4.73 & 11.75 \\
\hline
\end{tabular}

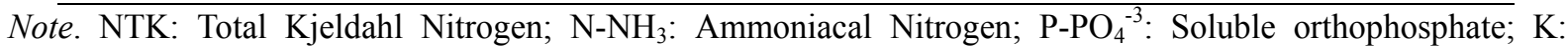
Potassium; Na: Sodium; pH: Hydrogen ionic potential and CE: Electrical Conductivity.

At 15 and 30 days after transplanting was evaluated the net assimilation of $\mathrm{CO}_{2}$ under radiation photosynthetically active saturating (A) $\left(\mu \mathrm{mol} \mathrm{CO} \mathrm{Cm}^{-2} \mathrm{~s}^{-1}\right)$, leaf transpiration (E) $\left(\mathrm{mmol} \mathrm{H}_{2} \mathrm{O} \mathrm{m}^{-2} \mathrm{~s}^{-1}\right)$, stomatal conductance (gs) ( $\mathrm{mol} \mathrm{H}_{2} \mathrm{O} \mathrm{m}^{-2} \mathrm{~s}^{-1}$ ), and internal concentration of $\mathrm{CO}_{2}(\mathrm{Ci})(\mathrm{ppm})$ evaluated on sunny days from 9:00 am to 12:00 am and measured on the fourth fully expanded leaf below of the apex.

These variables were evaluated using the infrared radiation photosensitive analyzer (Infra Red Gas Analyzer IRGA, model Li-6400XT, LI-COR). With the gas exchange index it was possible to determine the efficient use of water by the ratio $(\mathrm{A} / \mathrm{E})\left[\left(\mu \mathrm{mol} \mathrm{m} \mathrm{m}^{-2} \mathrm{~s}^{-1}\right)\left(\mathrm{mmol} \mathrm{H} \mathrm{H}_{2} \mathrm{O} \mathrm{m}^{-2} \mathrm{~s}^{-1}\right)^{-1}\right]$ and the instantaneous efficiency of carboxylation $(\Phi \mathrm{c})\left[\left(\mu \mathrm{mol} \mathrm{m} \mathrm{s}^{-2}\right)\left(\mu \mathrm{mol} \mathrm{mol}^{-1}\right)^{-1}\right]$ by the ratio (A/Ci) (Melo et al., 2009).

The photon flux (PPFD) maintained in the IRGA chamber was $1.200 \mu \mathrm{mol} \mathrm{m}^{-2} \mathrm{~s}^{-1}$ in the two evaluations. The average temperature inside the greenhouse at the time of data collection was $40.2{ }^{\circ} \mathrm{C}$.

The results were submitted to analysis of variance, performing the comparison between averages by the Tukey test at 5\% probability using the SISVAR 5.3 software as support (Ferreira, 2011).

\section{Results and Discussion}

There was a significant effect among the treatments for the internal concentration of $\mathrm{CO}_{2}(\mathrm{Ci})$, leaf transpiration (E), stomatal conductance (gs), net assimilation of $\mathrm{CO}_{2}$ under radiation photosynthetically active saturating (A) for the 15 DAT (Figure 1).

The variables liquid photosynthesis (Figure 1C), stomatal conductance (Figure 1B), internal concentration of $\mathrm{CO}_{2}$ (Figure 1A) and transpiration (Figure 1D) behaved similarly for plants grown on soil fertilized with the mixture of cassava wastewater and human urine (T5), this treatment presented the highest averages in relation to the others. 

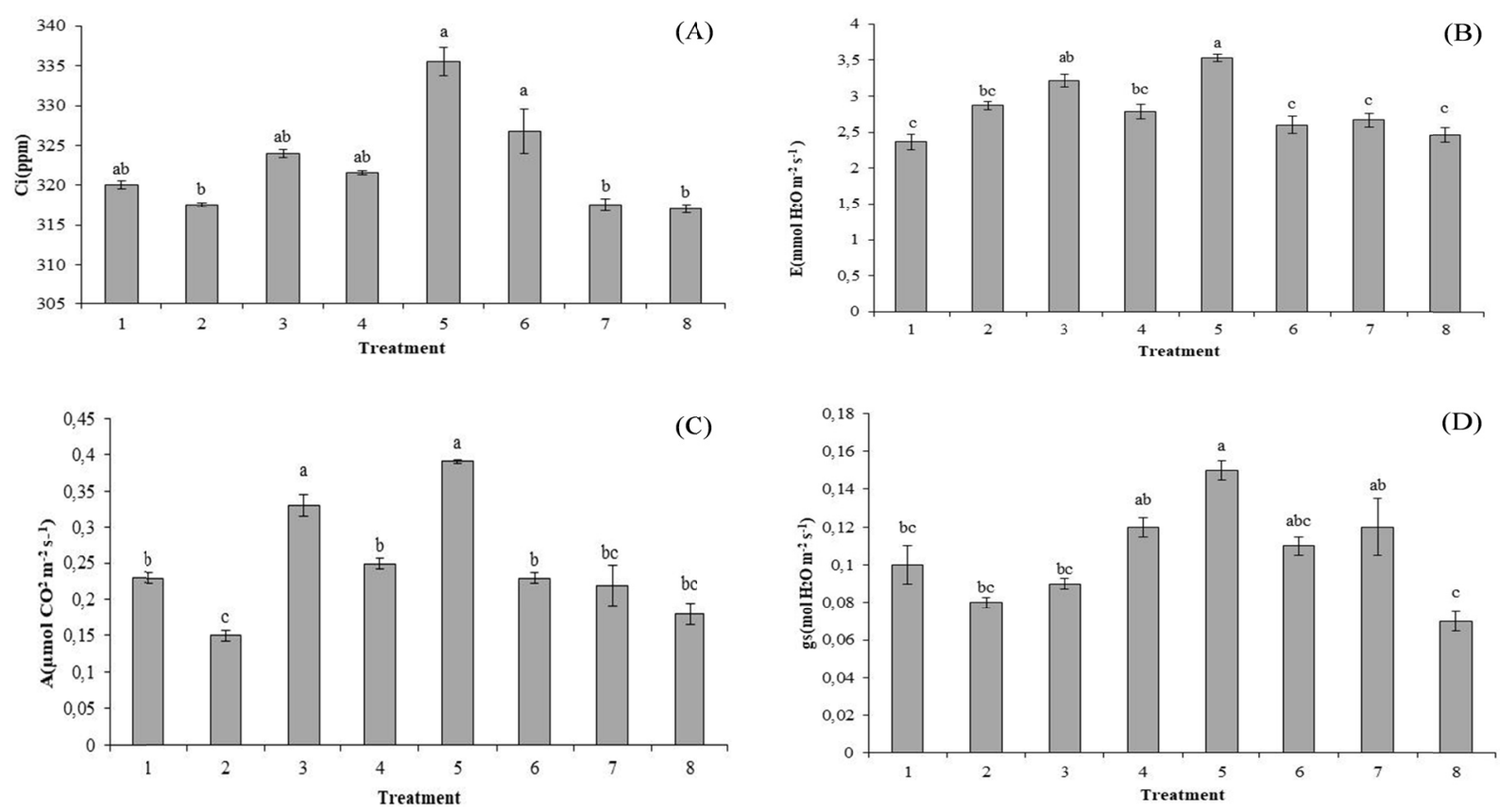

Figure 1. Internal concentration of $\mathrm{CO}_{2}(\mathrm{Ci}, \mathrm{ppm})$, transpiration $\left(\mathrm{E}, \mathrm{mmol} \mathrm{H}_{2} \mathrm{O} \mathrm{m}^{-2} \mathrm{~s}^{-1}\right)$, net assimilation of $\mathrm{CO}_{2}$ under radiation photosynthetically active saturating $\left(\mathrm{A}, \mu \mathrm{mol} \mathrm{CO} \mathrm{Cm}^{-2} \mathrm{~s}^{-1}\right)$ and stomatal conductance ( $\mathrm{gs}$, mol $\mathrm{H}_{2} \mathrm{O} \mathrm{m}^{-2} \mathrm{~s}^{-1}$ ) in capsicum plants cultivated in soil fertilized with human urine and/or cassava wastewater treated at 15 DAT

Note. The numbers correspond to: bovine manure: 1 - (T1-EB); 2 - NPK (T2-NPK); 3 - fertilization with human urine treated $(\mathrm{T} 3-\mathrm{UH}) ; 4$ - cassava wastewater treated (T4-MANI); 5 - human urine plus cassava wastewater treated $(\mathrm{T} 5-(\mathrm{T} 3)+(\mathrm{T} 4))$, twice the volume of human urinetreated $(\mathrm{T} 6-2 \mathrm{x}(\mathrm{T} 3))$, twice the volume of cassava wastewater treated $(\mathrm{T} 7-2 \mathrm{x}(\mathrm{T} 4))$ and twice the volume of human urine plus twice the volume of cassava wastewater treated (T8-2x(T3+T4)). The sequence 1-8 represents the $\mathrm{T} 1$ to $\mathrm{T} 8$ treatments respectively. Averages \pm standard error; Different letters indicate significant differences among the eight treatments $(p<0.05)$.

The increase in stomatal conductance observed in Figure 1D referring to treatment 5 (fertilization with cassava wastewater plus human urine) may be associated with a high concentration of potassium present in the cassava wastewater.

In a study by Gondin et al. (2015) cultivating beet with and without mineral fertilization, and with organic fertilization, he observed that the treatment with mineral fertilization (NPK) may have caused the increase of the gs of the beet. In a study conducted by Catuchi et al. (2012) with soybean, potassium fertilization increased the stomatal conductance, because $\mathrm{K}$ can confer an adequate dynamics of the gs, besides being a macronutrient of great importance in the activation of the carboxylase function of the rubisco enzyme, which contributes to a higher photosynthetic activity (Prado, 2008).

The relation of net assimilation of $\mathrm{CO}_{2}$ under radiation photosynthetically active saturating to the plants cultivated in the soil fertilized with treatment 5 was $61.53 \%$ higher than those cultivated with mineral fertilization (T2), and $41.02 \%$ higher than the fertilized soil with bovine manure tanned (T1). Photosynthesis is intrinsically associated with stomatal opening or stomatal conductance, and governed by internal $\mathrm{CO}_{2}$ concentration (Grulke et al., 2007), so the results are in line with the study cited above.

The crops cultivated in soil fertilized with $\mathrm{T} 5$ presented photosynthesis of $0.39 \mu \mathrm{mol} \mathrm{CO} \mathrm{Cm}^{-2} \mathrm{~s}^{-1}$, for T3 the value was $0.33 \mu \mathrm{mol} \mathrm{CO} \mathrm{m}^{-2} \mathrm{~s}^{-1}$ and for T4 $0.23 \mu \mathrm{mol} \mathrm{CO} \mathrm{CO}_{2} \mathrm{~m}^{-2} \mathrm{~s}^{-1}$. Human urine treated had an alkaline $\mathrm{pH}$ of 9.32 and the cassava wastewater an acidic $\mathrm{pH}$ of 4.73 , so $\mathrm{T} 5 \mathrm{had}$ a $\mathrm{pH}$ of 7.15 , where human urine treated may have aided in reducing the acidic $\mathrm{pH}$ of the cassava leaving the solution near to neutrality. The optimum nutrient availability range of the soil for the crops is at $\mathrm{pH}$ between 5.5 and 6.5 , where these, mainly macronutrients present in the cassava and human urine treated are more available to the plant (Malavolta, 1979).

Among all treatments applied, treatment 5 (fertilization with human urine plus cassava wastewater) provided the best results for all the gas exchange variables evaluated at $15 \mathrm{DAS}$ of yellow capsicum. Comparing treatment 5 
with treatment 2 (fertilization with NPK), there was an increase of $5.22 \%$ for $\mathrm{Ci}, 46.66 \%$ for gs, $18.69 \%$ for $\mathrm{E}$, and $61.54 \%$ for $\mathrm{A}$, thus highlighting the efficiency in the gas exchange parameters of the plants grown in soil fertilized with cassava wastewater plus human urine (treatment 5) and mineral fertilization with NPK (treatment 2), thus having a significant effect for these variables.

The crops cultivated in soil fertilized with $\mathrm{T} 8$ were those that obtained the lowest averages of liquid photosynthesis (A) at $15 \mathrm{DAT}$, with a drop of $0.39 \mu \mathrm{mol} \mathrm{CO} \mathrm{Cm}^{-2} \mathrm{~s}^{-1}$ for soil fertilized with T5 (human urine plus cassava) for $0.15 \mu \mathrm{mol} \mathrm{CO} \mathrm{Cm}^{-2} \mathrm{~s}^{-1}$ for soil fertilized with $\mathrm{T} 8$ (twice the volume of human urine plus twice the volume of cassava), which corresponds to a decrease of $61.53 \%$. There was a significant effect between the majority of the treatments on the efficient use of water (UEA) and instantaneous efficiency of carboxylation ( $\varphi c$ ), at the level of $5 \%$ of probability. The fertilization of the foundation with human urine plus cassava wastewater (treatment 5-T5) favored the increase of both the UEA and for $\Phi \mathrm{c}$, thus, it is noticed that for these variables, the plants grown in these conditions stand out positively in relation to the other treatments evaluated.

It was possible to verify that the crops that were cultivated in soil fertilized with mineral fertilization (T2), were the ones that presented the lowest rates of UEA and $\Phi \mathrm{c}$ in relation to all other treatments. What could have influenced this fall in the UEA and $\Phi \mathrm{c}$ in the plants cultivated in soil fertilized with the treatment T2 was at the high temperature inside the greenhouse, since the experimental units fertilized with human urine and cassava showed visually longer residual time of soil moisture after irrigation event, a fact that may be related to the physical-chemical characteristics of the cassava (Table 2).

Table 2. Mean values for water efficiency (UEA) and instantaneous carboxylation efficiency ( $\varphi c)$ for 15 DAT under different types of organic-mineral fertilization

\begin{tabular}{lll}
\hline FV & UEA $\left(\mu \mathrm{mol} \mathrm{m}^{-2} \mathrm{~s}^{-1}\right)\left(\mathrm{mmol} \mathrm{H}_{2} \mathrm{O} \mathrm{m}^{-2} \mathrm{~s}^{-1}\right)^{-1}$ & $\Phi \mathrm{c}\left(\mu \mathrm{mol} \mathrm{m}^{-2} \mathrm{~s}^{-1}\right)\left(\mu \mathrm{mol} \mathrm{mol}^{-1}\right)^{-1}$ \\
\hline T1-EB & $0.098474 \mathrm{ab}$ & $0.000729 \mathrm{c}$ \\
T2-NPK & $0.053294 \mathrm{c}$ & $0.000483 \mathrm{~d}$ \\
T3-UH & $0.102918 \mathrm{ab}$ & $0.001019 \mathrm{ab}$ \\
T4-M & $0.091294 \mathrm{ab}$ & $0.000788 \mathrm{bc}$ \\
T5-UH+M & $0.111349 \mathrm{a}$ & $0.001209 \mathrm{a}$ \\
T6-2xUH & $0.089997 \mathrm{ab}$ & $0.000714 \mathrm{~cd}$ \\
T7-2xM & $0.084221 \mathrm{abc}$ & $0.000703 \mathrm{~cd}$ \\
T8-2xUH +M & $0.072832 \mathrm{bc}$ & $0.000568 \mathrm{~cd}$ \\
CV $(\%)$ & 12.75 & 10.89 \\
DMS & 0.03175 & 0.00024 \\
\hline
\end{tabular}

Note. Means followed by the same letter, in the same column do not differ statistically from each other, by the Tukey test at 5\% probability; Fc: Calculated F; CV: Coefficient of variation; DMS: minimum significant difference.

According to Machado et al. (2005) the instantaneous efficiency of carboxylation (Фc) has a close relationship with ( $\mathrm{Ci}$ ) and (A), corroborating with the results of the present work, where the lowest values of $\mathrm{Ci}$ and $\mathrm{A}$ were also observed in T2 (Figures 1A and 1C). The author also emphasizes that the optimum temperature where the values of this variable are more expressive is between $20-30{ }^{\circ} \mathrm{C}$, what could have justified this fall was the fact that the average temperature instantaneous inside the greenhouse was approximately $40{ }^{\circ} \mathrm{C}$.

The capsicum crops cultivated in soil fertilized with T8 presented the largest significant reductions in gas exchange, mainly for gs, where the highest value was $0.21 \mathrm{~mol} \mathrm{H}_{2} \mathrm{O} \mathrm{m}^{-2} \mathrm{~s}^{-1}$ when applied the treatment 4 (cassava wastewater) and $0.07 \mathrm{~mol} \mathrm{H}_{2} \mathrm{O} \mathrm{m}^{-2} \mathrm{~s}^{-1}$ when applied the treatment 8 to 30 DAT (Figure 2). 

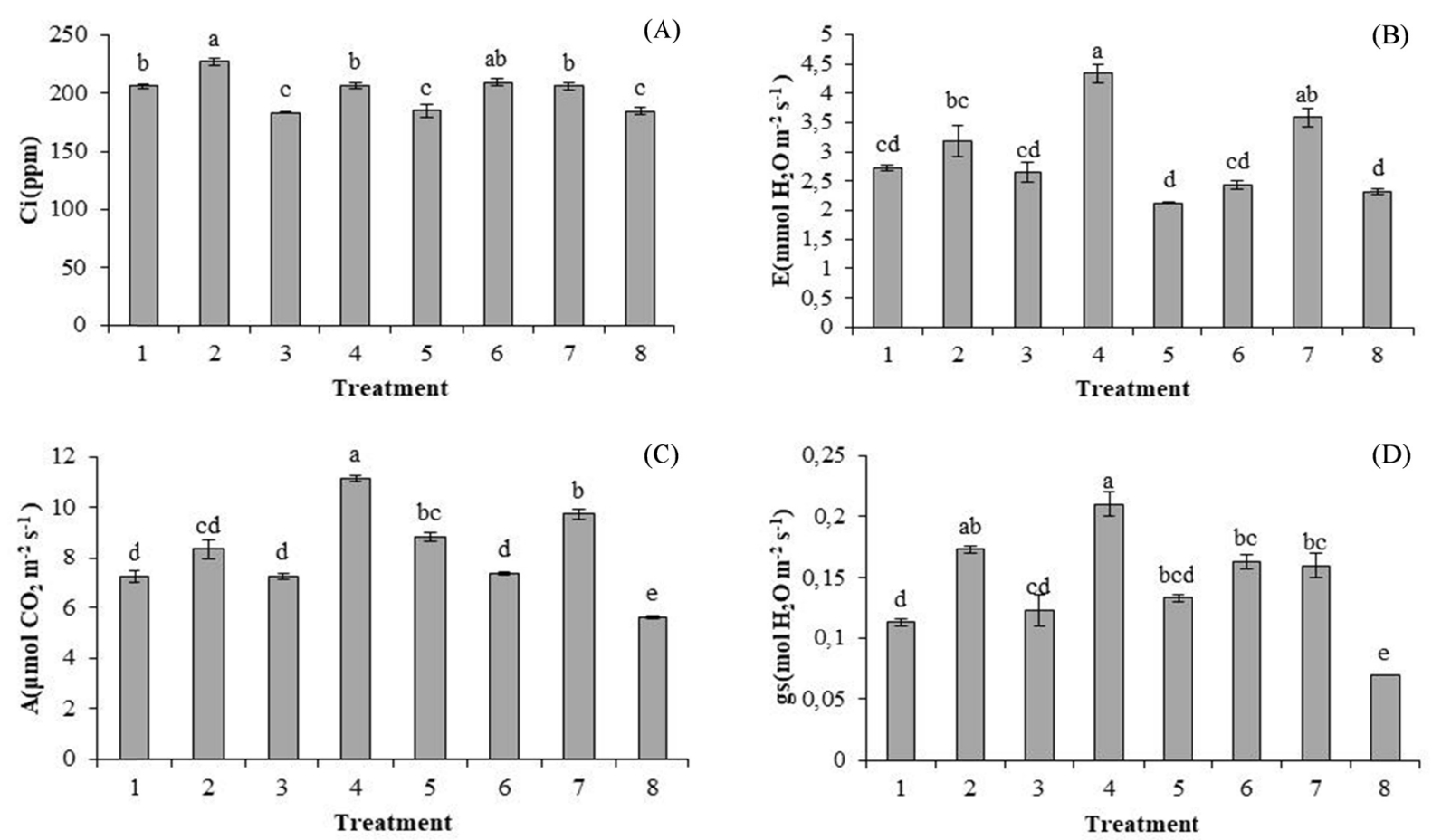

Figure 2. Internal concentration $\mathrm{CO}_{2}\left(\mathrm{Ci}\right.$, ppm), transpiration $\left(\mathrm{E}, \mathrm{mmol} \mathrm{H}_{2} \mathrm{O} \mathrm{m}^{-2} \mathrm{~s}^{-1}\right)$, net assimilation of $\mathrm{CO}_{2}$ under radiation photosynthetically active saturating $\left(\mathrm{A}, \mu \mathrm{mol} \mathrm{CO} \mathrm{Cm}^{-2} \mathrm{~s}^{-1}\right)$ and stomatal conductance ( $\mathrm{gs}$, mol $\mathrm{H}_{2} \mathrm{O} \mathrm{m}^{-2} \mathrm{~s}^{-1}$ ) in plants grown on soil fertilized with human urine treated and/or cassava wastewater at 30 DAT

Note. The numbers correspond to: bovine manure: 1 - (T1-EB); 2 - NPK (T2-NPK); 3 - fertilization with human urine treated $(\mathrm{T} 3-\mathrm{UH}) ; 4$ - cassava wastewater treated (T4-MANI); 5 - human urine plus cassava wastewater treated $(\mathrm{T} 5-(\mathrm{T} 3)+(\mathrm{T} 4))$, twice the volume of human urinetreated $(\mathrm{T} 6-2 \mathrm{x}(\mathrm{T} 3))$, twice the volume of cassava wastewater treated $(\mathrm{T} 7-2 \mathrm{x}(\mathrm{T} 4))$ and twice the volume of human urine plus twice the volume of cassava wastewater treated $(\mathrm{T} 8-2 \mathrm{x}(\mathrm{T} 3+\mathrm{T} 4))$. Averages \pm standard error. Different letters indicate significant differences among the eight treatments $(\mathrm{p}<0.05)$.

The same effect could be observed for the variables $\mathrm{E}$ and $\mathrm{A}$ (Figures $2 \mathrm{~B}$ and $2 \mathrm{C}$ ), with percentage differences for these treatments for E was $53.34 \%$ and for A was $50.54 \%$ higher respectively for 30 DAT, demonstrating that for both 15 DAT and 30 DAT the T8 presented the lowest averages for the gas exchange variables (Figure 2).

This effect can be justified by the application of a human urine and cassava wastewater volume equivalent to concentrations of $\mathrm{N}$ and $\mathrm{K}$ above that recommended by (Novais et al., 1991), thus causing deleterious effects to the culture, affecting the parameters of gas exchanges and consequently the final production.

In a study conducted by Costanzi et al. (2010) with Zoyisia japonica grass irrigated with different amounts of yellow water or human urine three times a week, they found that the frequency of irrigation and the amount of human urine applied was very high causing toxicity in plants.

In a study carried out by Araújo et al. (2015) with maize cultivation in a hydroponic forage system with substrate fertirrigated with human urine, they concluded that it is only feasible, from a productive point of view, the fertirrigations with a concentration of less than $6 \%$ of human urine.

The treatment that showed the best effect on plants at 30 DAT was T4. Treatments 1 (fertilization with bovine manure) and 2 (fertilization with NPK) did not present significant positive effects for any of the variables analyzed at 15 and 30 DAT.

The variables UEA and $\Phi c$ presented significant differences through the means comparison test, Tukey $(\mathrm{p}<0.05)$ at 30 DAT, through which it was observed that for the efficient use of water, treatment 5 was the one that presented the best result, standing out to treatments 1, 2 and 4 mainly, with a mean difference of $63.37 \%$. Regarding the other treatments, there weren't significant differences between them for the UEA variable, except for T6 (Table 3). 
Table 3. Mean values for water efficiency (UEA) and instantaneous carboxylation efficiency ( $\varphi c)$ for the 30 DAT under different types of organic-mineral fertilization

\begin{tabular}{lll}
\hline FV & UEA $\left(\mu \mathrm{mol} \mathrm{m}^{-2} \mathrm{~s}^{-1}\right)\left(\mathrm{mmol} \mathrm{H}_{2} \mathrm{O} \mathrm{m}^{-2} \mathrm{~s}^{-1}\right)^{-1}$ & $\Phi \mathrm{c}\left(\mu \mathrm{mol} \mathrm{m}^{-2} \mathrm{~s}^{-1}\right)\left(\mu \mathrm{mol} \mathrm{mol}^{-1}\right)^{-1}$ \\
\hline T1-EB & $2.653333 \mathrm{~b}$ & $0.0366670 \mathrm{bc}$ \\
T2-NPK & $2.640000 \mathrm{~b}$ & $0.0366670 \mathrm{bc}$ \\
T3-UH & $2.780000 \mathrm{~b}$ & $0.040000 \mathrm{abc}$ \\
T4-M & $2.583333 \mathrm{~b}$ & $0.05000000 \mathrm{a}$ \\
T5-UH+M & $4.123333 \mathrm{a}$ & $0.0466670 \mathrm{ab}$ \\
T6-2xUH & $3.026667 \mathrm{~b}$ & $0.0366670 \mathrm{bc}$ \\
T7-2xM & $2.730000 \mathrm{~b}$ & $0.0466670 \mathrm{bc}$ \\
T8-2xUH+M & $2.436667 \mathrm{~b}$ & $0.03000000 \mathrm{c}$ \\
\hline CV $(\%)$ & 8.44 & 11.29 \\
DMS & 0.68556 & 0.01290 \\
\hline
\end{tabular}

Note. Means followed by the same letter, in the same column do not differ statistically from each other, by the Tukey test at 5\% probability; Fc: Calculated F; CV: Coefficient of variation; DMS: minimum significant difference.

For the carboxylation efficiency, the T4 treatment (cassava), as in most of the analyzed variables, was the one that provided the best result in relation to the other treatments, mainly in relation to $\mathrm{T} 1$ and $\mathrm{T} 2$, which are the organic fertilizers and minerals commonly used in agriculture, both conventional and familiar.

Capsicum plants cultivated in soil fertilized with the T8 treatment showed the lowest carboxylation efficiency, dropping from $0.050000\left[\left(\mu \mathrm{mol} \mathrm{m}^{-2} \mathrm{~s}^{-1}\right)(\mu \mathrm{mol} \mathrm{mol})^{-1}\right]$ in $\mathrm{T} 4$ to $0.030000\left[\left(\mu \mathrm{mol} \mathrm{m} \mathrm{s}^{-1}\right)\left(\mu \mathrm{mol} \mathrm{mol}^{-1}\right)^{-1}\right]$ in $\mathrm{T} 8$, thus indicating that the relationship between liquid photosynthesis and internal concentration of $\mathrm{CO}_{2}$ was reduced as a function of the other treatments, an effect that will directly affect the production of photoassimilates essential for the growth and production of yellow capsicum (Satrapo hybrid).

\section{Conclusions}

(1) In the conditions under which the research was carried out, the crops of the yellow capsicum (Satrapo hybrid) cultivated in soil fertilized with human urine plus cassava wastewater were the ones with the best internal concentration of $\mathrm{CO}_{2}\left(\mathrm{Ci}\right.$, ppm), transpiration $\left(\mathrm{E},\left(\mathrm{H}_{2} \mathrm{O} \mathrm{m} \mathrm{m}^{-2} \mathrm{~s}^{-1}\right)\right.$, net assimilation of $\mathrm{CO}_{2}$ under radiation photosynthetically active saturating $\left(\mathrm{A}, \mu \mathrm{mol} \mathrm{CO}_{2} \mathrm{~m}^{-2} \mathrm{~s}^{-1}\right)$ and stomatal conductance $\left(\mathrm{gs}, \mathrm{mol} \mathrm{H}_{2} \mathrm{O} \mathrm{m} \mathrm{m}^{-2}\right.$ ), water use (UEA) by the relation $(\mathrm{A} / \mathrm{E})\left[\left(\mu \mathrm{mol} \mathrm{m} \mathrm{m}^{-2} \mathrm{~s}^{-1}\right)\left(\mathrm{mmol} \mathrm{H}_{2} \mathrm{O} \mathrm{m}^{-2} \mathrm{~s}^{-1}\right)^{-1}\right]$ and the instantaneous efficiency of carboxylation $(\Phi \mathrm{c})\left[\left(\mu \mathrm{mol} \mathrm{m} \mathrm{s}^{-1}\right)\left(\mu \mathrm{mol} \mathrm{mol}^{-1}\right)^{-1}\right]$ at 15DAT;

(2) For the 30 DAT, the treatment that presented the highest results for the variables mentioned above was the use of only cassava wastewater treated as biofertilizer;

(3) Treatment 8 (twice the volume of human urine treated plus twice the volume of cassava wastewater) affected negatively the gas exchanges of the capsicum at 15 and 30 DAT;

(4) Research is needed to legitimize an ideal recommendation of yellow water and cassava wastewater in the fertilization of the capsicum crop, in order not to harm the production of the crop and to bring profitability to the rural worker.

\section{References}

Araújo, N. C., Amorim, C. M., Oliveira, R., Meira, C. M. B. S., \& Oliveira, S. J. C. (2015). Cultivo hidropônico de milho fertirrigado com urina humana como fonte alternativa de nutrientes. Irriga, 20(4), 718-729. https://doi.org/10.15809/irriga.2017v1n1

Cardoso, E., Cardoso, D., Cristiano, M., Silva, L. D., Back, A. J., Bernadim, A. M., \& Paula, M. D. S. (2009). Use of manihot esculenta, crantz processing residue as biofertilizer in corn crops. Research Journal of Agronomy, 3(1), 1-8.

Catuchi, T. A., Guidorizzi, F. V. C., Guidorizi, K. A., de Moraes Barbosa, A., \& Souza, G. M. (2012). Respostas fisiológicas de cultivares de soja à adubação potássica sob diferentes regimes hídricos. Pesquisa Agropecuária Brasileira, 47(4), 519-527. https://doi.org/10.1590/s0100-204x2017000800003 
Costanzi, R. N., Frizzo, E., Dombeck, D., Colle, G., Rosa, J. F., Maibuk, L. A. C., \& Fernandes, M. D. S. P. (2010). Reuso de água amarela. Revista de Engenharia e Tecnologia, 2(1), 9-16.

Dantas, M. S., Rolim, M. M., Duarte, A. de S., Pedrosa, E. M., Tabosa, J. N., \& Dantas, D. da C. (2015). Crescimento do girassol adubado com resíduo líquido do processamento de mandioca. Revista Brasileira de Engenharia Agricola e Ambiental-Agriambi, 19(4), 350-357. https://doi.org/10.1590/1807-1929/agriambi. v21n9p657-662

Ferreira, D. F. (2011). Sisvar: a computer statistical analysis system. Ciência e Agrotecnologia, 35(6), 1039-1042.

Filgueira, F. A. R. (2008). Novo manual de Olericultura: Agrotecnologia moderna na produção e comercialização de hortaliças (p. 421). Viçosa, MG: UFV.

Goldstein, J. (2012). Waste. In F. Trentmann (Ed.), The Oxford Handbook of the History of Consumption (pp. 326-347). Oxford University Press, Oxford.

Gondim, O. A. R., Santos, J. L. G., Lira, R. P., Brito, M. E. B., \& Pereira, F. H. F. (2015). Atividade fotossintética da beterraba submetidas a adubação mineral e esterco bovino. Revista Verde de Agroecologia e Desenvolvimento Sustentável, 10(2), 61-65.

Grulke, N. E., Neufeld, H. S., Davison, A. W., Roberts, M., \& Chappelka, A. H. (2007). Stomatal behavior of ozone-sensitive and -insensitive coneflowers (Rudbeckia laciniata var. Digitata) in Great Smoky Mountains National Park. New Phytologist, 173(1), 100-109.

Lima, G. S., Nobre, R. G., Gheyi, H. R., dos Anjos Soares, L. A., Pinheiro, F. W. A., \& Dias, A. S. (2015). Growth, content of sodium, chlorideand ion relation in castor bean under salt stress and nitrogen fertilization. Comunicata Scientiae, 6(2), 212-223. https://doi.org/10.14295/cs.v7i1.1372

Lind, B. B., Ban, Z., \& Bydén, S. (2001). Volume reduction and concentration of nutrients in human urine. Ecological Engineering, 16(4), 561-566. https://doi.org/10.1016/S0925-8574(00)00107-5

Machado, E. C., Schmidt, P. T., Medina, C. L., \& Ribeiro, R. V. (2005). Respostas da fotossíntese de três espécies de citros a fatores ambientais. Pesquisa Agropecuária Brasileira, 40(12), 1161-1170. https://doi.org/10.1590/s0100-204x2017000800003

Malavolta, E. (1979). ABC da adubação (4th ed., p. 256). São Paulo: Ceres. https://doi.org/10.1590/0034-737x 201764040003

Melo, A. S., Pedro, C. D. D. S. J., Fernande, D., Barbosa, L. F. S. M. E., \& Dantas, B. J. D. (2009). Alterações das características fisiológicas da bananeira sob condições de fertirrigação. Ciência Rural, 39(3), 733-741. https://doi.org/10.1590/0103-8478cr20141247

Netting, R. M. S. (1993). Smallholders, householders: Farm families and the ecology of intensive, sustainable agriculture. Stanford University Press, USA.

Novais, R. F., Neves, J. C. L., \& Barros, N. D. (1991). Ensaio em ambiente controlado. Métodos de pesquisa em fertilidade do solo (pp. 189-253). Brasília: Embrapa-SEA.

Oliveira, C. D. D., Braz, L. T., Santos, J. M. D., Banzatto, D. A., \& Oliveira, P. R. D. (2009). Resistência de pimentas a nematóides de galha e compatibilidade enxerto/porta-enxerto entre híbridos de pimentão e pimentas. Horticultura Brasileira, 27(4), 520-526. https://doi.org/10.1590/s0102-053620170112

Oliveira, F. A., da Silva Sá, F. V., Pereira, F. H. F., de Araújo, F. N., de Paiva, E. P., \& de Almeida, J. P. N. Comportamento físiológico e crescimento de plantas de melancieira sob diferentes concentrações de solução nutritiva. Revista Brasileira de Agricultura Irrigada, 10(1), 439. https://doi.org/10.1590/S141543662000000300025

Prado, R. M. P. (2008). In R. M. Prado (Ed.), Nutrição de plantas (pp. 161-181). São Paulo: UNESP.

Ribeiro, A. C., Guimarães, P. T. G., \& Alvarer, V. H. (1999). Recomendações para uso de corretivos e fertilizantes em Minas Gerais (p. 359). Viçosa: Comissão de Fertilidade do Solo do Estado de Minas Gerais. Retrieved March 23, 2017, from http://www.dpv24.iciag.ufu.br/new

Sediyama, M. A. N., Vidigal, S. M., Santos, M. R., \& Salgado, L. T. (2009). Rendimento de pimentão em função da adubação orgânica e mineral. Horticultura Brasileira, 27(1), 294-299. https://doi.org/10.1590/s0102053620170112 


\section{Copyrights}

Copyright for this article is retained by the author(s), with first publication rights granted to the journal.

This is an open-access article distributed under the terms and conditions of the Creative Commons Attribution license (http://creativecommons.org/licenses/by/4.0/). 